\title{
Baby PISA: Dangers that can Arise when Foundations Shift
}

\author{
Alan Pence: A Call and Commentary
}

Alan Pence is Professor, School of Child and Youth Care, University of Victoria. He is the co-author, with Gunilla Dahlberg and Peter Moss, of Beyond Quality in Early Childhood Education and Care - a volume first published in 1999 which remains germane to the issues discussed in this Commentary.

An inter-related set of issues, with implications for Early Childhood Education, Care and Development at local, national and international levels, arose in 2016 in regards to a call for tenders from OECD inviting bids to develop and pilot what some have referred to as a 'Baby PISA'. Many will be familiar with the OECD PISA testing program (Organization for Economic Cooperation and Development, Programme for International Student Assessment), as its triennial release of results that rank countries by the test performance of their fifteen year olds on various academic subjects, invariably generates international controversy. The fact of such triennial controversies, makes it all the more surprising and concerning that a proposal to create, in essence, a 'PISA' for 5 year olds has proceeded to a development stage with virtually no public, or early childhood field visibility or input. The connection between the PISA for 15 year olds and the one proposed for 5 year olds (the International Early Learning Study, or IELS) is clear in OECD’s 2016 'Call for Tenders':

"In time, the information [from the IELS] can also provide information on the trajectory between early learning outcomes and those at age 15, as measured by PISA. In this way, countries can have an earlier and more specific indication of how to lift the skills and other capabilities of its young people" (OECD, 2016, p. 9).

Hearing about the OECD's plans in summer 2016, and concerned to raise wider awareness of what is in the offing as well as to encourage critical discussion of a project with potentially serious consequences for young children and their services, Prof. Peter Moss reached out to colleagues in eight other countries, none of whom indicated more than a passing awareness of the OECD's plans and its 'call for tenders'. What began as a set of concerns in regards to a new 
OECD initiative: appropriateness of a PISA inspired international test for 5 year olds, subsequently morphed into a second set: OECD's failure to engage with concerns raised by Moss et al. (the nine colleagues).

Insofar as there are potentially significant implications for the early childhood field and for young children and their families with this initiative, and since the proposal has had very limited visibility internationally, it was felt that a brief overview of the initiative and activities to date was warranted for the readers of this journal. What follows is: a brief overview of the development of a critical response led by Prof. Moss with colleagues from eight additional countries; efforts to engage in dialogue with the OECD; publication of an article by the nine colleagues; the IELS issue being taken up by the Reconceptualizing Early Childhood Education (RECE) network at their International Conference Oct. 30-Nov. 3, 2016; and a second critical article published on behalf of RECE by Mathias Urban and Beth Swadener.

Following some online discussions regarding the initiative by the nine in June 2016, and many of those members contacting government or OECD-connected individuals within their own country who might have knowledge of the initiative, the group decided efforts must be made to make the issue more visible. A contact with the journal Contemporary Issues in Early Childhood (CIEC), led to the August 2016 publication of, 'The OECD's International Early Learning Study: Opening for debate and contestation' (Moss, Dahlberg, Greishaber, Mantovani, May, Pence, Rayna, Swadener, \& Vandenbroeck).

Following the article's publication, Moss took the lead on behalf of the nine colleagues in contacting the OECD and making four specific proposals: 1) for OECD to provide a publishable response to the CIEC article; 2) for the group of 16 countries participating in the Scoping Group for the IELS to publicise and consult with the early childhood communities within their own country; 3) for OECD to invite one of the CIEC authors to speak at an upcoming OECD meeting in Paris planned for late October; and 4) for the OECD to set up a webpage devoted to the IELS including a background and latest information on its development. As of mid-January 2017 only one of the four has taken place, the creation of a webpage offering limited information. 
Following publication of the Moss et al. article and efforts to have the OECD respond to the four proposals, the IELS issue subsequently expanded to another venue for critique and action, being raised at the Reconceptualizing Early Childhood Education (RECE) conference that took place in Aotearoa/New Zealand October 30 - Nov. 3, 2016. The presentations and discussions taking place within the RECE were complemented by debates and discussions within other Aotearoa/New Zealand organizations, including the New Zealand Association for Research in Education (NZARE). In one of two related motions the NZARE approved: "That members of the NZARE call on the New Zealand Government to not participate in the OECD IELS and urge Government instead to continue the work already begun with the MOE early Childhood Research Policy Forum, designed to produce appropriate outcome measures for early childhood education linked to the principles and strands of Te Whariki." (Proposed: Alex Gunn, Seconded: Linda Mitchell, 2016).

The NZARE motion highlights the damage that initiatives such as the IELS with their universalist approach and technocratic tools can do at individual country and international levels. Moss et al. in their 2016 article start with a quote from Loris Malaguzzi, which speaks to the OECD's approach and its potential dangers: “Anglo-Saxon 'testology' which is nothing but a ridiculous simplification of knowledge, and a robbing of meaning from individual histories." (Malaguzzi in Cagliari, 2016).

Following the RECE Conference, Mathias Urban and Beth Swadener authored a critical assessment of the OECD-IELS, 'Democratic accountability and contextualised systemic evaluation', on behalf of RECE which was published in International Critical Childhood Policy Studies (December, 2016). In the abstract for that article Urban and Swadener note that the IELS "has received little attention from early childhood scholars and practitioners due not least to the absence of a meaningful consultation process." They go on to note that "We argue that emerging resistance from the field against decontextualized standardised assessment of children, and the nature of the information gathered will render IELS results largely meaningless for the stated purpose of improving early childhood experiences for all children." The article is linked to the RECE website which now includes over 170 scholars from around the world who have endorsed the statement. 
Following publication of the RECE statement, OECD offered a meeting with Urban, scheduled to take place in early February, with Moss also in attendance. It will provide an opportunity to seek further information from OECD, not least about the countries that have agreed to participate in the piloting of the IELS (so far only England has gone public on its participation). It will also be an opportunity to seek clarification on whether and if so how the OECD plans to engage with the wider early childhood community, both to disseminate information about this major new initiative and to debate the concerns and criticisms that are increasingly being voiced as people find out what is planned.

This Commentary is a Call for readers to access the articles published to date regarding the concerns raised here and to engage at local, national and international levels to help ensure that actions deemed important by a few are not allowed to be visited upon the many without an open and fully informed debate and opportunity for contestation. 


\section{References}

Cagliari P, Castegnetti M, Giudici C, Rinaldi, C., Vecchi, V., \& Moss, P. (Eds.) (2016) Loris Malaguzzi and the Schools of Reggio Emilia: A Selection of His Writings and Speeches 1945-1993. London: Routledge.

Gunn, A. \& Mitchell, L. (2016). ECE SIG motion approved at NZARE Conference, November 2016. (http://www.nzare.org.nz/portals/306/images/Files/ECE_2016_report.pdf)

Moss, P., Dahlberg, G., Grieshaber, S. Mantovani, S., May, H., Pence, A., Rayna, S., Swadener, B.B., \& Vandenbroeck, M. (2016). The Organisation for Economic Co-operation and Development's International Early Learning Study: Opening for debate and contestation. Contemporary Issues in Early Childhood, 17(3), 343-351.

(http://journals.sagepub.com/doi/full/10.1177/1463949116661126)

OECD. (2015). Call for tenders: International Early Learning Study.

(http://www.oecd.org/callsfortenders/CfT 100001420 International Early Learning Study.pdf)

Urban, M. \& Swadener, B.B. (2016). Democratic accountability and contextualised systemic evaluation. International Critical Childhood Policy Studies, 5(1), 6-18. (http://receinternational.org/RECE-comment-on-OECD-ICCPS.html) 